\title{
Developmental gene expression of antimicrobial peptide Protegrin-1 and effect of weaning on gene regulation of Protegrin-1 in piglets*
}

\author{
F.F. Han, Y.Z. Wang ${ }^{1}$, J. Feng, J. Guo and Z.R. Xu \\ The Key Laboratory of Molecular Animal Nutrition, \\ Ministry of Education, Institute of Feed Science, Zhejiang University \\ 164 Qiutao North Road, Hangzhou 310029, P.R. China
}

(Received 24 July 2006; revised version 24 October 2006; accepted 2 February 2007)

\begin{abstract}
Two experiments were conducted to evaluate developmental gene expression of antimicrobial peptide Protegrin-1 and effect of weaning on gene regulation of Protegrin-1 in piglets using semi-quantitative RT-PCR analysis. In experiment 1, total 15 female 28 day-age weanling Duroc $\times$ Landrace $\times$ Yorkshire piglets were divided into three groups. And 5 piglets in each group were slaughtered at 1, 14, 28, 42 and 56 day-age respectively, which were used to determine mRNA expression of Protegrin-1 at different ages. In experiment 2, 18 neonatal female piglets, divided into three groups (6 piglets of each group), were weaned at 21, 28 and 35 days of age, respectively. At the 21, 28 and 35 day-age before weaned, 3 piglets in each group were slaughtered, and bone marrow cells of piglets were sampled. Furthermore, additional 3 piglets in each group were slaughtered and sampling in 7 days after they were weaned. The samples were collected for detecting the effect of weaning on Protegrin-1 mRNA expression of piglets. The current results show that Protegrin-1 mRNA levels increased steadily in postnatal 1-28 day-age (pre-weaning). But after the piglets were weaned at 28 day-age, the levels of Protegrin- 1 gene expression were decreased markedly $(\mathrm{P}<0.05)$ from 28 to 42 day-age (14 days after weaning). From 42 days to 56 days, its expression levels were increased again. The results of experiment 2 showed that when the piglets were weaned at 21 days of age, the expression levels of Protegrin- 1 were decreased by $34 \%$ at the seventh day after weaning; when the piglets were weaned at 28 days of age, the expression levels of Protegrin- 1 were decreased by $51 \%$ at the seventh day after weaning; when the piglets were weaned at 35 days of age, the expression levels of Protegrin- 1 were decreased by $49 \%$ at the seventh day after weaning. Our results showed that weaning significantly decreased Protegrin-1 mRNA expression of piglets.
\end{abstract}

KEY WORDS: Protegrin-1, piglet, gene expression, weaning, day-age, reverse transcription polymerase chain reaction (RT-PCR)

\footnotetext{
* Supported by the National Natural Science Foundation of China (30571348) and New Century Excellent Talents in University (NECT-04-0543)

${ }^{1}$ Corresponding author: e-mail: yzwang@zju.edu.cn
} 


\section{INTRODUCTION}

Antimicrobial peptides are effective components of innate immunity and being evaluated as the first line of defense against microbial invasion (Boman, 1998; Lehrer and Ganz, 1999). Among these natural antimicrobial peptides, two major families have been characterized in mammals: defensins and cathelicidins (Gennaro and Zanetti, 2000). Cathelicidins are a group of structurally diverse antimicrobial peptides which are synthesized in the myeloid progenitor cells (Zanetti et al., 1995). Antimicrobial peptides of this family have been found in several mammalian species, including horse (Scocchi et al., 1999), cattle (Zanetti et al., 1990), pig (Zanetti et al., 1994) and mouse (Gallo et al., 1997). They are particularly abundant in porcine neutrophils (Kokryakov et al., 1993). Today, eleven antimicrobial peptides in pigs have been described. Protegrin-1 (Harwig et al., 1995) and PR-39 (Storice and Zanetti, 1993) are the most important two kinds among them (Gudmundsson et al., 1995; Zhang et al., 2000). Protegrin peptides were identified from porcine leukocytes and their cDNA isolated by RT-PCR cloning (Kokryakov et al., 1993). Protegrin-1 (PG-1) is an 18-amino-acid peptide isolated originally from porcine leucocyte cell (Kokryakov et al., 1993). This peptide displays a broad-range antimicrobial activity spectrum (Yasin et al., 1996) and has, therefore, excellent potential for pharmaceutical uses. The cationic nature of the peptide allows its interaction with the lipid matrix of bacterial membranes containing negatively charged lipids, but its antimicrobial activity itself depends on its ability to form pores in these membranes.

$\mathrm{Wu}$ et al. (1999) investigated the specific gene expression of PR-39 and Protegrin in porcine tissues during the first month of age. The result suggested that PR-39 and Protegrin mRNA was detected in the bone marrow, neutrophils, thymus, mesenteric lymph nodes, and liver at earlier ages of pigs. In addition, Wu et al. (2000) reported that lipopolysaccharide (LPS), interleukin-6 (IL-6) and retinoic acid (RA) unregulated PR-39 gene expression.

Furthermore, Wang et al. (2004b) evaluated developmental gene expression of antimicrobial peptide PR-39 and effect of zinc oxide on gene regulation of PR-39 in piglets. The investigation showed that the gene expression of PR-39 was age-dependent and would significantly decrease in piglets when the piglets were weaned at 35 days of age. Protegrin-1, the same as PR-39, is also one of the members of cathelicidin family in pigs, but the developmental expression of Protegrin-1 mRNA in piglets, especially the difference of Protegrin-1 mRNA expression of pre-weaning and post-weaning was not further studied.

In the current study, experiment 1 is conducted to determine the Protegrin-1 gene expression pattern at different ages and experiment 2 is conducted to detect whether weaning can affect Protegrin-1 expression in vivo at different weaning ages. 


\section{MATERIAL AND METHODS}

\section{Experiment 1}

Animal. Total 15 female piglets (Duroc $\times$ Landrace $\times$ Yorkshire) of three groups, each group of five piglets were euthanized under anaesthesia for sampling at 1, 14, 28, 42 and 56 days of age. These health piglets from three same breed litters were fed in a conventional environment before euthanasia. The piglets had been weaned at 28 days of age after birth. All the animal experiments were done according to the guidelines for animal experiments at the National Institute of Animal Health.

$R N A$ extraction. In order to investigate the developmental gene expression of porcine Protegrin-1, femurs of all pigs were dissected, and total RNA was isolated from bone marrow cells from littermate pigs at the indicated time using TRIzol Reagent (Invitrogen Life Technologies, Carlsbad, CA, USA) according to the manufacture's manual. Extracted RNA was dissolved in 30 $\mu \mathrm{l}$ ultra-pure water and used for RT-PCR assay. The purity and concentration of total RNA were checked using a spectrophotometer at 260 and $280 \mathrm{~nm}$.

RT-PCR assay. RT-PCR was performed in a thermocycler (Gene Amp PCR system 9600). Two microgram of RNA isolated from each sample was converted in single stand cDNA using Random primers $(500 \mu \mathrm{g} / \mathrm{ml}$, Promega Corporation, USA). Then $1 \mu \mathrm{cDNA}$ solution, obtained by reverse transcriptase reaction of total RNA, was used for templates of PCR amplification in a total volume of $50 \mu$. The PCR primer sets used are shown in Table 1. Primer sequences for

Table 1 Specific primers for RT-PCR of porcine Protegrin- 1 and $\beta$-actin

\begin{tabular}{llc}
\hline Gene & \multicolumn{1}{c}{ Oligonucleotide sequence } & Size of PCR product (bp) \\
\hline \multirow{2}{*}{ Protegrin-1 } & 5' - CCGTGCTTCGTGCTGTGGA -3'(S) & 355 \\
& 5' - TGCCGTCGCAACCGTCAT -3'(AS) & \\
\multirow{2}{*}{$\beta$-actin } & 5' - CGGGACCTGACCGACTACCT - 3'(S) & 411 \\
\hline
\end{tabular}

Protegrin-1 and $\beta$-actin gene were designed using the Primer Program of the Winsconsin Sequence Analysis Package (Genetics Computer Group, Inc.) based on known sequences deposited in Genbank. The optimum PCR primer concentration, $\mathrm{Mg}^{2+}$ concentration, annealing temperature and PCR reaction cycles to give a linear amplification of each transcript were determined by a preliminary experiment (data not shown). The PCR assay mixture contained the following components: $37.5 \mu 1$ nuclease-free water, $5 \mu 110 \times$ PCR reaction buffer, $3 \mu 1 \mathrm{MgCl}_{2}(25 \mu \mathrm{M})$, $1 \mu \mathrm{l}$ dNTPs mix, $1 \mu \mathrm{l}$ sense primer $(20 \mu \mathrm{M}), 1 \mu \mathrm{l}$ antisense primer $(20 \mu \mathrm{M})$ and 
$0.5 \mu \mathrm{l}$ Taq DNA polymerase ( $2 \mathrm{U} / \mu 1$, Promega). The optimum PCR reaction cycles and concentration of $\mathrm{Mg}^{2+}$ to give a linear amplification of each transcript were determined by a preliminary experiment (data not shown). PCR for Protegrin-1 and $\beta$-actin was done under the following thermal cycles: Protegrin- 1 at $94^{\circ} \mathrm{C}$ for $45 \mathrm{~s}, 58^{\circ} \mathrm{C}$ for $45 \mathrm{~s}$ and $72^{\circ} \mathrm{C}$ for $50 \mathrm{~s}$ for 29 cycles; $\beta$-actin at $94^{\circ} \mathrm{C}$ for $45 \mathrm{~s}, 58^{\circ} \mathrm{C}$ for $45 \mathrm{~s}$ and $72^{\circ} \mathrm{C}$ for $50 \mathrm{~s}$ for 29 cycles.

The concentration of Protegrin-1 mRNA at different ages was determined by the semi-quantitative RT-PCR method (Marone et al., 2001). Equal volume of the same sample cDNA was used for Protegrin- 1 and $\beta$-actin gene PCR, respectively as described previously. The component of PCR was same as the described above and the incubation cycles were 29 for Protegrin- 1 and $\beta$-actin amplification.

A $5 \mu 1$ portion of each PCR product was subjected to electrophoresis on a $1.5 \%$ agarose gel with ethidium bromide. Protegrin-1 gene PCR products were normalized according to the amount of $\beta$-actin detected in the same cDNA sample, and Protegrin- $1 / \beta$-actin ratios were calculated. The expression levels of Protegrin-1 gene in piglet bone marrow tissue at different ages were compared on the basis of Protegrin- $1 / \beta$-actin ratio.

\section{Experiment 2}

Animals. In experiment 2, three litters of neonatal piglets (Duroc $\times$ Landrace $\times$ Yorkshire) with close weight (six piglets of each group) were weaned at 21, 28 and 35 days of age, respectively. At the 21, 28 and 35 day-age before weaned, three piglets in each group were slaughtered, and bone marrow cells of piglets were sampling. Furthermore, additional three piglets in each group continued being raised for 7 days after weaning. Then they were slaughtered and sampling on the seventh day after weaning (28, 35 and 42 days of age). The bone marrow tissues of piglets were taken out under the sterile condition and kept in the liquid nitrogen immediately. The samples were collected for detecting the effect of weaning on the Protegrin-1 gene expression.

$R N A$ extraction. The method of RNA extraction is as described in Experiment 1. RT-PCR assay. The method of RT-PCR assay as described in Experiment 1.

\section{Data analysis}

Electrophoresis band intensities of the PCR products were quantified using Immage master VDS software. Mean Protegrin-1 mRNA expression levels normalized against $\beta$-actin in bone marrow tissues were presented in integrated optical density. Each value was analysed for statistical difference according to the Bonferroni/Dunn method. Differences between groups were analysed by the 
student t-test when two groups were analysed and analysis of variance (ANOVA) when more than two groups were analysed (Duncan, 1955).

\section{RESULTS AND DISCUSSION}

In the Experiment 1, we compared antimicrobial peptide Protegrin-1 mRNA expression of piglets at different ages by semi-quantitative PCR. RT-PCR allows the relative quantification of Protegrin-1 mRNA levels in bone marrow, although not the absolute quantification. The electrophoresis results of three pigs of each age group are shown in Figure 1, respectively.

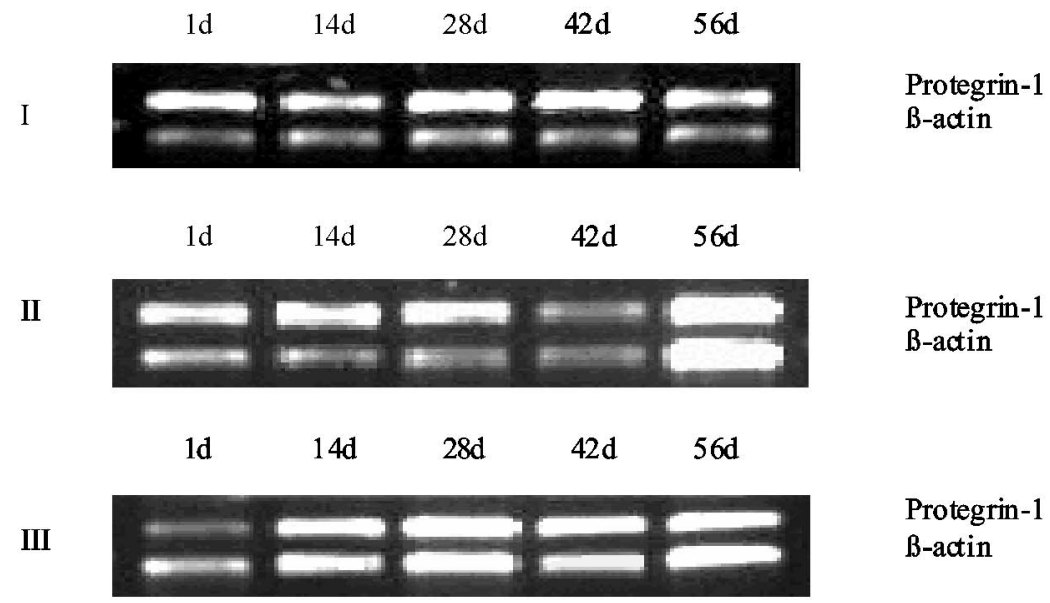

Figure 1. Electrophoresis results of RT-PCR product for Protegrin-1 and $\beta$-actin in the bone marrow of three piglets at 1, 14, 28, 42 and 56 day-age. I, II and III: The results from the first piglet, the second piglet and the third piglet in each age group, respectively

Developmental changes of Protegrin-1 mRNAamount were evaluated in postnatal 1-56 day-age female piglet's marrow using semi-quantitative RT-PCR analysis. The resulting $355 \mathrm{bp}$ amplification has been sequenced previously (Wang et al., 2004a) and was $100 \%$ homologous to the known sequences of Protegrin-1 deposited in Genbank. As shown in Figure 1, Protegrin-1 mRNA was detected at five stages (postnatal 1, 14, 28, 42 and 56 day-age) in bone marrow and the variety of Protegrin-1 gene expression was age-dependent. Protegrin-1 mRNA levels increased steadily in postnatal 1-28 day-age (pre-weaning), however Protegrin-1 mRNA levels of post-weaning pig (42 day-age) were significantly lower than pre-weaning pig (28 day-age) when piglets were weaned at 28 day-age. To the later post-weaning period (56 day-age), stronger Protegrin-1 mRNA expression was observed (Figure 2). 


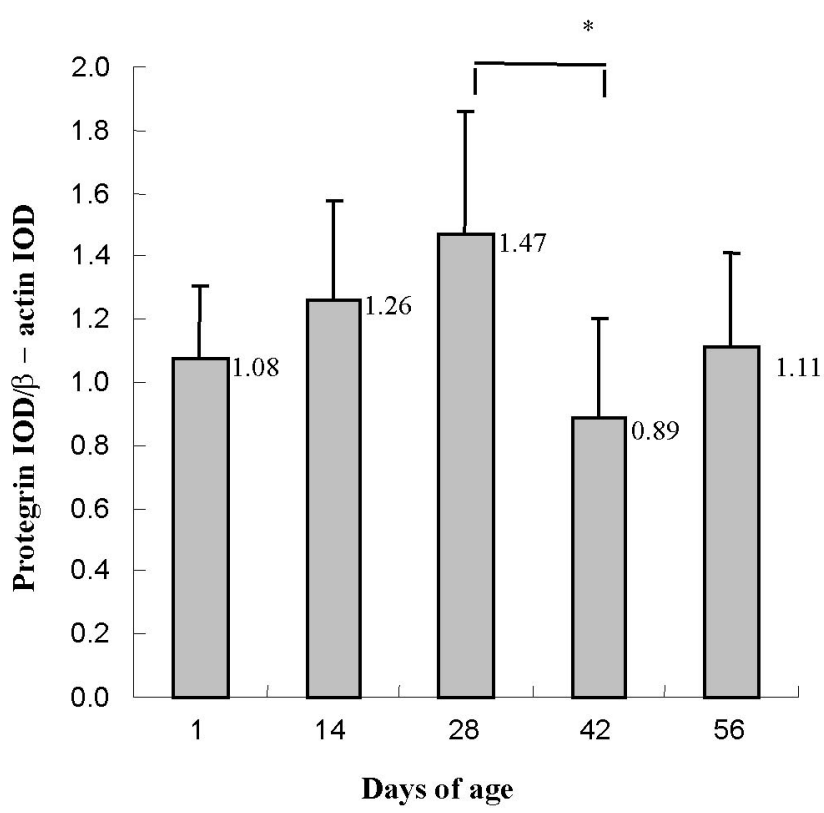

Figure 2. mRNA expression ratio of Protegrin-1 in bone marrow at 1, 14, 28, 42 and 56 day-age pigs. Bar show the mean expression amount of mRNA of three pigs as the ratio of the band intensity of each PCR product to the corresponding $\beta$-actin PCR product. * $\mathrm{P}<0.05$

We have ever investigated the developmental changes of another antimicrobial peptide, PR-39, mRNA levels of female piglet at postnatal 1-56 day-age (Wang et al., 2004b). The result suggested that the change of PR-39 gene expression were age-dependent. In the current experiment, we received the same result about Protegrin-1. And the variation tendency of Protegrin-1 gene expression also consisted with PR-39 from 1 to 56 days of age.

PR-39 and Protegrin-1, two porcine cathelicidins, are all synthesized in the bone marrow, stored as preforms in neutrophil granules and play a prominent role in host innate immunity (Ramanathan et al., 2002). But the development of piglet's immune system has a progressive course. The expression pattern of PR-39 and Protegrin-1 pre-weaning (1-28 days of age) may be a reflection of increased numbers of immature neutrophils in the piglets. The reduction of Protegrin-1 gene expression maybe relates to disappearance of some biological active factors in the milk and low feed intake in 1-2 weeks after the piglet weaned. After piglets were weaned, a nutrient weaning diet will be supplemented to weanling pigs. Stronger expression of Protegrin-1 in the later post-weaning (postnatal day 56) may reflect the positive effect of nutrition on Protegrin-1 gene expression or the developed maturation process of antimicrobial peptide Protegrin-1 itself. 
The result from Wu et al. (1999) also indicated that bone marrow cells showed abundant expression of Protegrin-1 in pigs at the first month of age, but they did not investigate the effect of weaning on Protegrin-1 mRNA expression of piglets. We further investigated the effect of different weaned ages on gene expression of antimicrobial Protegrin-1 in vivo and semi-quantitative RT-PCR was used to evaluate Protegrin-1 mRNA levels.

Experiment 2 was conducted to study the effect of different weaned ages on the amount of Protegrin-1 mRNA in bone marrow. The electrophoresis results of Protegrin-1 gene PCR production in different weaned day-age groups (three piglets in each group) are shown in Figure 3, respectively. Results from the

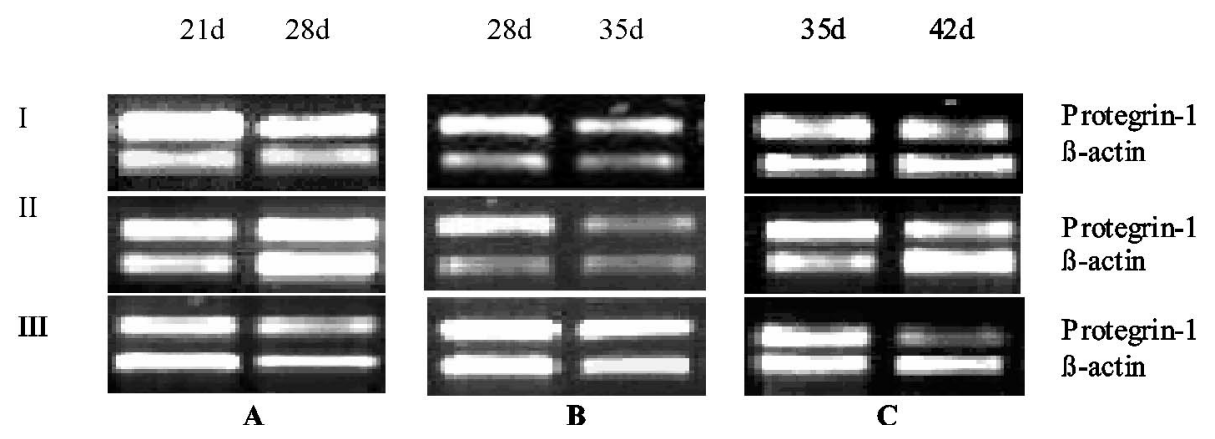

Figure 3. Electrophoresis results of RT-PCR product for Protegrin-1 and $\beta$-actin in the bone marrow of three piglets at different weanling-age. A, B, C were the electrophoresis results of piglets weaned at 21, 28 and 35 days of age respectively. I, II and III: The results from the first piglet, the second piglet and the third piglet in each age litter respectively

current experiment showed that the expression levels of Protegrin-1 at the 7th day after weaning was decreased significantly compared with the weaned days of age, no matter it is weaned on 21, 28 or 35 days of age. Compared with at 21 day-age (weaned at 21 day-age), the expression levels of Protegrin-1 at 28 day-age (at the seventh day after weaning) were decreased by $34 \%(\mathrm{P}<0.05)$. And when the piglets were weaned at 28 days of age and 35 days of age, the expression levels of Protegrin- 1 were decreased by $51 \%(\mathrm{P}<0.05)$ and $49 \%(\mathrm{P}<0.05)$, respectively at the seventh day after weaning (35 day-age and 42 day-age, respectively) (Figure 4 ). In the current study, the results implicate that Protegrin-1 expression was not only age-dependent but also significantly decreased by weaning in piglets.

Weaning is probably the most stressful time in a pig's life because of the many changes it must undergo (Hohenshell et al., 2000). The stress associated with weanling pigs at three to four weeks or younger often results in low feed intake, low weight gain, and diarrhoea (Hicks et al., 1998). The change from milk to solid feed, the absence of maternal immunoglobulins, the change of environment 
A

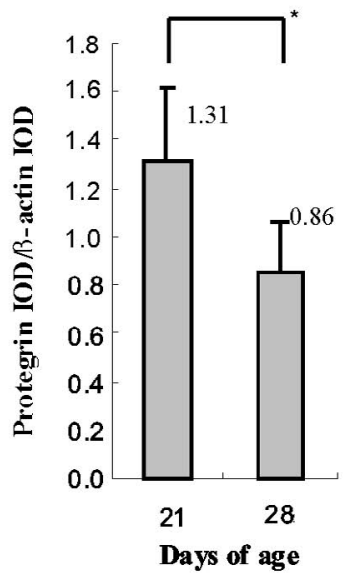

B

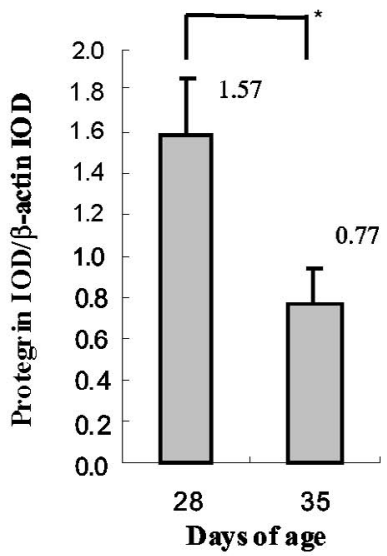

$\mathbf{C}$

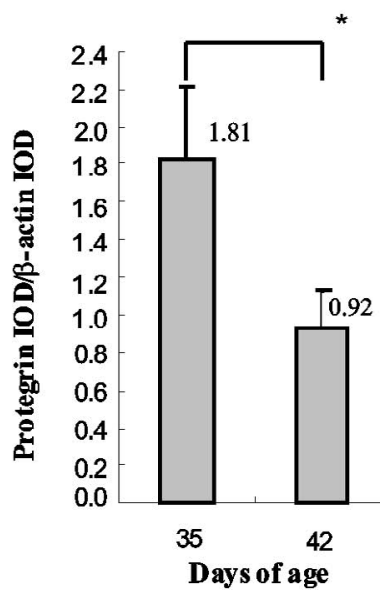

Figure 4. mRNA expression ratio of Protegrin-1 in bone marrow of different weanling-ages pigs. Bar show the mean expression amount of mRNA of three pigs as the ratio of the band intensity of each PCR product to the corresponding $\beta$-actin PCR product. A. weaned at 21 days of age; B. weaned at 28 days of age; $\mathrm{C}$. weaned at 35 days of age. $* \mathrm{P}<0.05$

and littermates, especially the change of immunology (Brown et al., 2002) can endanger the intestinal health of the animal (Metz and Gonyou, 1990). The immune system is immature at birth. Antibodies concentrated in sow colostrum compensate for this initial deficiency but protection is short and usually has disappeared by weaning time (i.e. in 3 to 5 weeks). The porcine own immune system begins developing at approximately three weeks of age, but is not able to mount an effective active immune response until the pig is to five weeks of age (Moore, 1996). At three- to five-week-old that piglets are usually weaned, the immune system of the pig is not fully developed and the biologically active factors derived from the maternal milk are disappeared, which makes the piglet vulnerable to the activity of pathogens.

\section{CONCLUSIONS}

The results from the current experiment implicated that wean resulted in decreasing in expression of non-specific immune factor Protegrin-1, and this is related to the stress of piglets encountered after weaning, and further easily caused performance lag, post-weaning diarrhoea and disease. It is unclear how Protegrin-1 might function in the developmental maturation of the porcine immune system. However, considering the critical early events involved in neonatal tolerance or 
immunization (Ridge et al., 1996), and the finding that other antimicrobial peptides has been shown to influence T cell immunity (Wu et al., 2000), it is possible that cathelicidins could participate in this critical stage of immune development.

\section{REFERENCES}

Boman H.G., 1998. Gene-encoded peptide antibiotics and the concept of innate immunity: an update review. Scand. J. Immunol. 48, 15-25

Brown D.C., Maxwell C.V., Davis M.E., Erf G.F., Singh S., 2002. Effects of segregated early weaning on systemic and enteric T lymphocyte subpopulations in pigs. J. Anim. Sci. 80, Suppl. $1,30-31$

Duncan D.B., 1955. Multiple range and multiple F tests. Biometrics 11, 1-42

Gallo R.L., Kim M., Kozak C.A., Zanetti M., Merluzzi L., Gennaro R., 1997. Identification of CRAMP, a Cathelin-related antimicrobial peptide expressed in the embryonic and adult mouse. J. Biol. Chem. 272, 13088-13093

Gennaro R., Zanetti M., 2000. Structural features and biological activities of the cathelicidin-derived antimicrobial peptides. Biopolymers 55, 31-49

Gudmundsson G.H., Magnusson K.P., Chowdhary B.P., Johansson M., Andersson L., Boman H.G., 1995. Structure of the gene for porcine peptide antibiotic PR-39, a cathelin gene family member: comparative mapping of the locus for the human peptide antibiotic FALL-39. Proc. Nat. Acad. Sci. USA. 92, 7085-7089

Harwig S.S., Kokryakov V.N., Swiderek K.M., Aleshina G.M., Zhao C., Lehrer R.I., 1995. Prophenin1 , an exceptionally proline-rich antimicrobial peptide from porcine leukocytes. FEBS Lett. 362, 65-69

Hicks T.A., McGlone J.J., Whisnant C.S., Kattesh H.G., Norman R.L., 1998. Behavioral, endocrine, immune, and performance measures for pigs exposed to acute stress. J. Anim. Sci. 76, 474-483

Hohenshell L.M., Cunnick J.E., Ford S.P., Kattesh H.G., Zimmerman D.R., Wilson M.E., Matteri R.L., Carroll J.A., Lay Jr. D.C., 2000. Few differences found between early and late weaned pigs raised in the same environment. J. Anim. Sci. 78, 38-49

Kokryakov V.N., Harwig S.S., Panyutich E.A., Shevchenko A.A., Aleshina G.M., Shamova O.V., 1993. Protegrins: leukocyte antimicrobial peptides that combine features of corticostatic defensins and tachyplesins. FEBS Lett. 327, 231-236

Lehrer R.I., Ganz T., 1999. Antimicrobial peptides in mammalian and insect host defense. Curr. Opin. Immunol. 11, 23-27

Marone M., Mozzetti S., Ritis D.D., Pierelli L., Scambia G., 2001. Semiquantitative RT-PCR analysis to assess the expression levels of multiple transcripts from the same sample. Biol. Proced. Online. 3 (1), 19-25

Metz J.H.M., Gonyou H.W., 1990. Effect of age and housing conditions on the behavioural and haemolytic reaction of piglets to weaning. Appl. Anim. Behav. Sci. 27, 299-309

Moore C., 1996. Managing early weaned pigs. West. Hog J. 17 (3), 4-7

Ramanathan B., Davis E.G., Ross C.R., Blecha F., 2002. Cathelicidins: microbicidal activity, mechanisms of action, and roles in innate immunity. Microbes Infect Mar. 4, 361-372

Ridge J.P., Ephraim J., Matzinger P., 1996. Neonatal tolerance revisited: turning on newborn T cells with dendritic cells. Science 271, 1723-1726

Scocchi M., Bontempo D., Boscolo S., Tomasinsig L., Giulotto E., Zaneetti M., 1999. Novel cathelicidins in horse leukocytes. FEBS Lett. 457, 459-464 
Storice P., Zanetti M.A., 1993. cDNA derived from pig bone marrow cells predicts a sequence identical to the intestinal antibacterial peptide PR-39. Biochem. Biophys. Res. Commun. 196, 1058-1065

Wang Y.Z., Liu G.F., Chu X.N., Han F.F., 2004a. PCR amplication, cloning and sequencing of protegrin-1 gene of porcine antibacterial peptide. J. Zhejiang Univ. 30, 336-339

Wang Y.Z., Xu Z.R., Lin W.X., Huang H.Q., Wang Z.Q., 2004b. Developmental gene expression of antimicrobial peptide PR-39 and effect of zinc oxide on gene regulation of PR-39 in piglets. Asian-Austr. J. Anim. Sci. 17, 1635-1640

Wu H., Zhang G.L., Minton J.E., Ross C.R., Blecha F., 2000. Regulation of cathelicidin gene expression: Induction by lipopolysaccharide, Interleukin-6, retinoic acid, and Salmonella enterica serovar typhimurium infection. Infec. Immunity 68, 5552-5558

Wu H., Zhang G.L., Ross C.R., Blecha F., 1999. Cathelicidin gene expression in porcine tissues: Roles in ontogeny and tissue specificity. Infec. Immunity 67, 439-442

Yasin B., Lehrer R.I., Harwig S.S., Wagar E.A., 1996. Susceptibility of Chlamydia trachomatis to protegrins and defensins. Infec. Immunity 64, 4863-4866

Zanetti M., Gennaro R., Romeo D., 1995. Cathelicidins: a novel protein family with a common proregion and a variable C-terminal antimicrobial domain. FEBS Lett. 374, 1-5

Zanetti M., Litteri L., Gennaro R., Horstmann H., Romeo D., 1990. Bactenecins, defense polypeptides of bovine neutrophils, are generated from precursor molecules stored in the large granules. J. Cell Biol. 111, 1363-1371

Zanetti M., Storici P., Tossi A., Scocchi M., Gennaro R., 1994. Molecular cloning and chemical synthesis of a novel antibacterial peptide derived from pig myeloid cells. J. Biol. Chem. 269, 7855-7858

Zhang G., Ross C.R., Blecha F., 2000. Porcine antimicrobial peptides: new prospects for ancient molecules of host defense. Vet. Res. 31, 277-296 